\title{
WHEN ASYLUM IS THE ONLY WAY OUT: MACEDONIA'S ASYLUM LEGISLATION BEFORE AND AFTER THE REFUGEE CRISIS
}

\author{
Angelina STANOJOSKA, PhD \\ Faculty of Law, University "St.Kliment Ohridski" - Bitola \\ E-mail: angelinastanojoska@uklo.edu.mk \\ Julija JURTOSKA, MA \\ Faculty of Law, University "St.Kliment Ohridski" - Bitola \\ E-mail: julijajurtoska@yahoo.com
}

\begin{abstract}
:
Starting the refugee crisis and the influx of different categories of people moving to and through the territory of the Republic of Macedonia has shown how legal and practical weaknesses Macedonia and the other countries of the region have. Although, most of the migrants and refugees passing through the Macedonian territory, did not seek asylum here, but in the EU member countries, a necessity for changes in the provisions of the Asylum Law emerged. In the light of the above, using the normative and comparative method, the paper analyses the 2015/2016 refugees and migrant crisis situation in the Republic of Macedonia, the legal challenges, mostly the Asylum Law amendments and their compatibility with the EU's Common European Asylum System.
\end{abstract}

Keywords: Asylum, European Union, migrant, refugee, theRepublic of Macedonia

\section{Introduction}

The Republic of Macedonia was an inevitable crossing point during the influx of migrants from the Middle East who were seeking sanctuary in the EU member countries. The pick of the migration flow was in 2015/2016 where the number of refugees and migrants that where crossing the Macedonian borders got up to 750.000 (Regional Refugee and Migrant Response Plan For Europe Eastern Mediterranean and Western Balkans Route, 2016), but Macedonia as a small country that was caught up in an ongoing political crises, did not have the capacity for a proper response without the help from the international community. The severity of this situation prompted a fast and appropriate legal improvement regarding the provisions on humanitarian 
aid to refugee, the provisions on unaccompanied foreign minors, and the procedures for the vulnerable categories of migrants.

Around half of the refugees and migrants that entered into Macedonian territory in 2015 declared their intention to apply for asylum, and that was the reason why the necessary changes in the existing Asylum Law (Official Gazette of the Republic of Macedonia 49/03, 66/07, $142 / 08,146 / 09,166 / 12,27 / 13,101 / 15,152 / 15,55 / 16,71 / 16)$ were made in June 2015 when the National Assembly passed the Law of Amending and Addition of the Law on Asylum and Temporary Protection (Official Gazette of the Republic of Macedonia, 101/15, 152/15, 55/16, 71/16).

This situation did not brought to light only the insufficient and inadequate legal solutions in the Macedonian legal system, but also the need of a comprehensive cooperation and collaboration with international and national agencies and institutions, NGO's and other relevant subject regarding the improvement of services and interventions in attaining minimum humanitarian standards in the reception and assistance sites.

In the next chapters of this paper we will give a retrospective of the policies and actions undertaken by the government and state bodies and institutions regarding the refugees and migrant crisis in 2015/2016, the international documents containing provisions about refugees and migrants that Macedonia has signed and ratified and the national legal provisions regarding the Asylum procedure before and after the influx of large numbers of refugees and migrants.

\section{Macedonian Migration Policy}

With the large number of migrant crossing the Macedonia-Greece border and the estimated future arrivals, with the lack of a consistent cooperation with Greek authorities, prompt the following political and institutional solutions from Macedonia.

At first the policies and decisions were made on a daily bases trying to win over the international support and gain political points in the national political scene, with negative attitude towards migrants and refugees who were seen as people who were illegally crossing the border and not as possible asylum seekers. That eventually had a negative reflection on the actions regarding the fact that these people only wanted a safe passage through Macedonian territory. After that began the phase of proper registration and organized transport from the southern to the northern border and finally the phase of building metal fences and selective passage of refugees and migrants regarding their nationality, preceded with a nationalistic political atmosphere from the leading political parties (Spasov, 2016).

Regarding the institutional response to these crises we can say that it was consistent with the crisis management law. That meant that a risk assessment should be done to assess the situation and give a report with the identified security threats and risks from the Crisis Management Center. From this report a number of proposals were made to all relevant institutions, such as the president as commander in-chief of the armed forces, the government, and the ministries of defense, interior, labor, transport and health as well as the local authorities from the affected municipalities (Deliso, 2015). 
A special Unit for Border Affairs and Migration was established in the Ministry of Interior and was responsible for security and safe management of Macedonian borders, the Ministry of Labor and Social Policy was responsible for providing acceptable services and socioeconomic integration during the times of stay in Macedonia for refugees and migrants and also special protection for children without parents, asylum seekers and other vulnerable groups (ChudoskaBlazhevska and Juberias, 2016).

Two of the most relevant policy documents regarding migrants and refugees are both Strategies for integration of refugees and alians for different time periods. The first one for the time period 2008-2015 was the first step towards a better social protection, accommodation and health care, and made crucial changes regarding the opportunities for future employment and education (Ministry of Labor and Social Policy, 2008). The second one for the time period 20172027 came in a different political climate when Macedonia was overwhelmed with a large number of refugees and migrants and was in need of improving the policies which were incorporated in the previous Strategy. The new Strategy addressed the different challenges that were not present when refugees from the region were in question, and those were the different cultural background and linguistic barriers set between Middle East refugees and migrants and Macedonian citizens. Also, this strategy incorporates solutions for each and every category of person who have rights under the Macedonian Asylum Law (Ministry of Labor and Social Policy, 2017).

\section{Macedonian first asylum law and its legal solutions}

Macedonia is a signature country of the Convention and Protocol relating to the Status of Refugees from 1951 and 1967 respectively, and also of the Convention relating to the status of stateless persons from 1994. That means that Macedonia guaranties the right to asylum to foreigners and stateless persons which are prosecuted because of their democratic and political views and activities.

The right to asylum is guaranteed in article 29 of the Macedonian Constitution, but also within this article is given the right to foreigners to enjoy all the freedoms and rights which are set forward in the Constitution.

The Law on Asylum and Temporary Protection was adopted in 2003 (Official Gazette of the Republic of Macedonia 49/03) and its provisions incorporated the fundamental rights given in the Universal Declaration for Human Rights, the Convention and Protocol relating to the Status of Refugees, the Convention against Torture and the European Convention for Human Rights. This Law regulates the conditions and procedure for granting of the right of asylum to an alien or a stateless person, who are seeking recognition of the right of asylum in the Republic of Macedonia, and also the right to a temporary protection, the procedure to grant this right and the rights and duties of persons from both of these categories.

Further in the legal provisions of this law are given the definitions of the persons who have the right of asylum (recognized refugee and a person under humanitarian protection), incorporating the principle of non-refoulement in article 7 (which stipulates that the persons who 
have right of asylum cannot be expelled or returned if there is a treat to their life, freedoms or rights). Also, asylum seekers have the right to family reunification with members of their nuclear family.

The procedure for recognition of the right of asylum begins with an application from the asylum seeker when he enters the territory of the Republic of Macedonia and the request should be made to the border police or in the nearest police station. The application can be given in written form or orally in a language that the asylum seeker understands and uses. If the asylum seeker has residents in Macedonia the application should be submitted in the Sector for Asylum and even aliens that made illegal entrance or reside illegally in Macedonia have the right to apply for asylum, but under one condition, to submit the application immediately or if he reports himself to the nearest police station and give an explanation for his/her illegal entry. After the application had been submitted the asylum seeker is photographed and fingerprinted (Articles 15-18).

Asylum seekers need to present relevant documentation regarding their identity, visas, marital status, travel tickets etc. in original. They have the right to an interpreter and unaccompanied minors or mentally disabled persons shell be given a guardian in accordance to the legal provisions from the Family Law. During the procedure and the interviewing of the asylum seeker the public is excluded.

The final chapter of the procedure is the decision that can be positive, meaning the asylum application will be accepted or negative, the application will be rejected. The asylum seeker has the right to appeal the decision and during that procedure the decision cannot be executed.

In one of the chapters of the Asylum law are given the rights and duties of the asylum seekers. During the period of time when asylum seekers are awaiting for the final decision from the relevant authorities they have the right to residence, accommodation and care in the Reception Center, basic health services, work assignments inside of the Reception Center and communication with the High Commissioner for Refugees and NGO's which provide legal assistance regarding the procedure of recognition of the right to asylum.

Since its adoption the Law on Asylum and Temporary Protection has been amended several times. The first amendment in 2007 (Official Gazette 66/07) was made in direction of harmonizing the national law with the EU Directive on Asylum (Council of EU, 2005) and implementing the remarks in this area made in the Report from the Commission of the European Communities (Commission of the European Communities, 2006). The novelty in this amendment is adding a new article 4a which incorporates the definition of Person under subsidiary protection "A person under subsidiary protection is an alien, who is not qualified as recognized refugee, but to whom the Republic of Macedonia will recognize the right to asylum and will allow him to stay on her territory, because of the existing reasons for believing that if this person is returned in the state where he has citizenship, or if he is a stateless person, in the state where he had last residents, he will face a real risk of enduring serious injuries, such as death penalty or execution; torture or inhuman or degrading treatment or serious and individual treats to his life or person as a civilian".

The following amendment was made in 2008 (Official Gazette, 142/08) in which the term 'person under humanitarian protection' was changed with 'person under subsidiary protection' 
and also changes were made regarding the right of the asylum seeker to an adequate legal remedy and the chance to start an administrative dispute against the decision made by the Sector for asylum before an appropriate court.

In 2009 (Official Gazette, 164/09) the amendments were made in the direction of incorporating the provisions from article 26.1 from the Asylum Procedures Directive regarding the first country of asylum "A country can be considered to be a first country of asylum for a particular applicant for asylum if: $s / h$ has been recognized in that country as a refugee and s/he can still avail $\mathrm{him} / \mathrm{herself}$ of that protection; or s/he otherwise enjoys sufficient protection in that country, including benefiting from the principle of non-refoulement" (Article 9a from the Law on Asylum). A new article 23a was added in which were defined the categories of Vulnerable people with disabilities and the permit of stay for persons under subsidiary protection has to last at least 1 year (Article 58).

Most of the changes to the Law on Asylum and Temporary Protection were made with the amendments from 2012 (Official Gazette, 166/12) when were incorporated new provisions regarding the definitions about asylum seekers and the request for asylum; actions that can lead to prosecution defined in article $1 A$ from the Convention relating to the status of refugees from 1951, which institutions can lead the prosecutions about serious law violations, free legal help, further elaboration on which country is seen as safe and free third country, the assessment of facts and circumstances that are crucial for making the decision of granting of denying asylum, in which cases the application for asylum can be considered to be withdrawn, clarification of the duties that the asylum seeker have and also about the personal information that need to be contained in the integrated database for foreigners, including data for asylum, visa and migration.

\section{Current legal solutions in the Republic of Macedonia regarding the Asylum Procedure (Amendments from 2015 and 2016)}

The changes of the Law on Asylum and Temporary Protection which were made with the amendments from 2015 (Official Gazette,101/15 and 152/15) are the ones in the direction of making a distinction between the intent for asylum application and the formal aspect of such application (when a person actually applies for an asylum status in the country). Such amendments were a necessary step in the process of prevention of illegal migration, but on the other hand, those provisions would help the potential asylum applicants during their asylum application and during the process of decision. The process of changes in the Law on asylum and temporary protection, actually was a harmonization with EU regulation. Namely, with the Council Directive 2001/55/ EC of 20 July 2001 on minimum standards for giving temporary protection in the event of a mass influx of displaced persons and on measures promoting a balance of efforts between Member States in receiving such persons and bearing the consequences thereof; the Directive 2011/95/ EU of the European Parliament and the Council of the EU of 13 December 2011 on standards for the qualification of third-country nationals or stateless persons as beneficiaries of international protection, for a uniform status for refugees or for persons eligible for subsidiary protection, and for the content of the protection granted (Qualification Directive); the Directive 2013/32/EU of the 


\section{Security}

European Parliament and of the Council of 26 June 2013 on common procedures for granting and withdrawing international protection and the Directive 2013/33/EU of the European Parliament and of the Council of 26 June 2013 laying down standards for the reception of applicants for international protection.

Namely, the amendments of the Law on asylum and temporary protection gave the potential asylum applicants the possibility to move through the country legally by filling out a document stating their intention of applying for asylum status. The potential asylum applicant has 72 hours to either apply for asylum in the Department for asylum in the Reception Center for asylum applicants or to leave the country (art.16).

The last amendments of the Law on asylum and temporary protection were made in 2016 (Official Gazette, 55/16 and 71/16). These amendments included the principle of family reunification which can only be exercised after three years from the moment the asylum applicant was granted asylum (art.8, p.3), which later on is pointed out from the EU as a problem, because it is not in accordance to the Family Reunification Directive (Directive 2003/86/EU).

Also, these amendments included the term safe third country and its definition. Namely, the Geneva Conventions and the Asylum Procedures Directive consider a safe country, the country where there is a democratic system and where there is no general danger of persecution, torture or inhuman or degrading treatment or punishment, no threat of violence and no armed conflict. According to Macedonian Law on asylum and temporary protection, a safe third country, member country of the European Union, NATO member country or EFTA member country is every country that has ratified and applies the provisions from the Convention relating to the status of refugees from 1951 and the European Convention on Human Rights, including the standards for effective legal mean, and also has established an asylum application according to Law and in accordance to the Convention relating to the status of refugees from 1951 (art.10a).

Any asylum application coming from a person who wants to enter or has illegally entered the territory of the Republic of Macedonia, coming from a safe third country, EU, NATO or EFTA member state, will be taken as unfounded in accordance with article 35 of the Law on asylum and temporary protection, taking into account the principle of non - refoulement from article 7 of the Law on asylum and temporary protection. The 2016 Commission Report also addresses few concerns regarding these provisions of the Law on asylum and temporary protection, especially because applications made by asylum seekers from safe third countries are always considered unfounded (Stanojoska, 2018), which is contrary to the Asylum Procedures Directive.

\section{Strategy for integration of refugees and aliens in the Republic of Macedonia for the period 2017 - 2027}

In 2008, Macedonia had its first Strategy for Integration of Refugees for the time period of 2008 - 2015 and an Action Plan for its implementation. In this period the state, gradually started to take care of social protection, accommodation and health insurance. The existence of the Strategy besides helping each refugee to benefit from his/her rights of social protection, 
accommodation and health insurance, was crucial for plans for individual or family integration. The Strategy 2008 - 2015 was positively used in direction towards integration and social inclusion of Kosovo refugees, which are now socially integrated into Macedonian society.

The 2017 - 2027 Strategy is a public policy document and is directed towards protection and integration of individuals which under the Law for asylum and temporary protection, are:

- individuals with recognized refugee status;

- individuals under subsidiary protection;

- asylum seekers;

- aliens that are legally staying in the Republic of Macedonia.

The newly established Center for refugees and aliens integration (body established with the Strategy) should help the Government in the integration process. Being a multidisciplinary, the Center has the possibilities to support the integration process by employment activities and professional training activities. Its long-term obligations are to become a consultative center, where refugees can get informed and use services such as housing, health and social protection, education, plans for individual or family integration. Also, it accents the need for better future social inclusion of refugees, mentioning the example with Roma people who originate from Kosovo and their decision to live among other Roma people in Shuto Orizari neighborhood. Actual social inclusion should help refugees to be accepted in other, mostly heterogonous neighborhoods, and will prevent their future marginalization.

\section{Conclusion}

The development of the Asylum Law in the Republic of Macedonia, even though it is relatively new, still in its short period of time from the first adopted law to the last amendments, has been improved so it can absorb and reflect the current migration problems and needs of the asylum seekers. Also, the legislators through the process of amending had in mind the need of harmonization of the Macedonian Asylum Law to the relevant European Union law from this area and their proper practical implementation.

Still Macedonian authorities are faced with problems when it comes to managing the different migration flows and a system of protection-sensitive screening of persons entering the country has not been implemented and that affects the effectiveness of the procedure for identification, profiling, referral and follow up on specific needs. Another problem is the lack of capacity of the border officials when it comes to recognizing the persons with international protection needs, including asylum seekers and the shortage of information about the right to seek asylum available at the borders.

In its observation UNHCR (UNHCR, 2015: 6-9) concluded that the police stations outside of Skopje do not prioritize asylum applicants and they direct them to the police stations in Skopje to pursue their application there. The registration forms are lacking very basic biographical data, because interpretation is not available at the police stations. A gender sensitive approach is almost nonexistent, and specific needs are not identified or taken into account at this initial stage 


\section{Securitity}

of the asylum procedure and these results in treatment that is not appropriately followed up with relation to their gender, age, or other specific needs.

When it comes to the Asylum procedure, the increase of asylum applications has given us a real picture about the shortcomings and to one of the main impediments to effective, efficient, and fair asylum procedure, which is the small administrative capacity when it comes to adequate equipment and proper budgetary support. An ongoing problem is the lack of interpretation that is provided to the asylum seeker and that reflects the outcome of the asylum procedure in a negative way. Also, the procedure at the first instance is really slow and with many delays, and when it comes to the decisions the Section for Asylum rarely made on the grounds of merits and they do not reflect the statement of the applicant as a whole, but only selective parts that suit them and without proper background checks about the facts and information's regarding the country of origin and finally they are based upon inadequate legal reasoning's.

This means that in the Republic of Macedonia we have made the needed and appropriate changes and amendments to the Law on Asylum and Temporary Protection, which means that the legal provisions can be implemented in an effective and efficient way if we have the much needed professionalism among the relevant authorities, institutions and administrative staff that make the first contact with the asylum seekers and should guide and advise them during the application procedure, the procedure in front of the first instance institutions and the procedures regarding the legal remedies.

\section{References}

1. Chudoska-Blazhevska, I. and Juberia, C. F. (2016) "Macedonia in the 2015 Refugee Crisis" in: Balkanika. No.7. p.p. 217-244;

2. Commission of the European Communities. (2006) "Commission Staff Working Document the former Yugoslav Republic of Macedonia 2006 Progress Report". Commission of the European Communities. (available at: https://ec.europa.eu/neighbourhood-enlargement/ sites/near/files/pdf/key_documents/2006/nov/fyrom_sec_1387_en.pdf);

3. Deliso, C. (2015) "Macedonian migration policy and the future of Europe". Balkanalysis, the 23rd of December 2015, http://www.balkanalysis.com/macedonia/2015/12/23/ macedonian-migration-policy-and-the-future-of-europe/ (visited on 21.05.2018);

4. European Commission. (2015) "Commission staff working document: The Former Yugoslav Republic of Macedonia Report 2015. Accompanying the document Communication from the Commission to the European Parliament, the Council, the European Economic and Social Committee and the Committee of the regions", European Commission: Brussels (available at: https://ec.europa.eu/neighbourhood-enlargement/sites/near/files/pdf/ key_documents/2015/20151110_report_the_former_yugoslav_republic_of_macedonia. pdf), (visited on 28.05.2018) 
5. Government of the Republic of Macedonia: Secretariat for European Affairs. (2015). "National Program for law harmonization with EU law: Revision 2016 - 2018". Government of the Republic of Macedonia;

6. Law on Asylum and Temporary Protection. Official Gazette of the Republic of Macedonia. 49/03, 66/07, 142/08, 146/09, 166/12, 27/13, 101/15, 152/15, 55/16, 71/16. Skopje;

7. Ministry of Labor and Social Policy. (2008) "Strategy for integration of refugees and aliens in the Republic of Macedonia 2008-2015". Skopje: Ministry of Labor and Social Policy;

8. Ministry of Labor and Social Policy. (2017) 'Strategy for integration of refugees and aliens in the Republic of Macedonia for the period 2017 - 2027'. Ministry of Labor and Social Policy, July 2017 http://www.mtsp.gov.mk/content/pdf/ 